\section{Reconstruction of sea-surface temperatures in the Canary Islands during Marine Isotope Stage 11}

Thibault Clauzel ${ }^{\mathrm{a}}{ }^{\mathbb{D}}$, Chloé Maréchal $^{\mathrm{b}}$, François Fourel ${ }^{\mathrm{c}}$, Abel Barral ${ }^{\mathrm{a}}$, Romain Amiot ${ }^{\mathrm{a}}$, Juan-Francisco Betancort ${ }^{\mathrm{d}}$, Alejandro Lomoschitz ${ }^{\mathrm{e}}$, Joaquín Mecod, Christophe Lécuyer ${ }^{\mathrm{a} *}{ }^{\S}$

a'Laboratoire de Géologie de Lyon, CNRS UMR 5276, Université Claude Bernard Lyon 1, France

bobservatoire des Sciences de l'Univers de Lyon, Université Claude Bernard, Lyon 1, France

'Laboratoire d'Ecologie des Hydrosystèmes Naturels et Anthropisés, CNRS UMR 5023, Université Claude Bernard, Lyon 1, France

${ }^{\mathrm{d} D e p a r t a m e n t o ~ d e ~ B i o l o g i ́ a, ~ U n i v e r s i d a d ~ d e ~ L a s ~ P a l m a s ~ d e ~ G r a n ~ C a n a r i a, ~} 35017$ Las Palmas de Gran Canaria, Canary Islands, Spain

eInstituto de Oceanografía y Cambio Global, Unidad Asociada de Investigación, desarrollo e innovación al Consejo Superior de Investigaciones Científicas, Universidad de Las Palmas de Gran Canaria, 35017 Las Palmas de Gran Canaria, Canary Islands, Spain

*Corresponding author e-mail address: christophe.lecuyer@univ-lyon1.fr (C. Lécuyer).

\section{Abstract}

The study of paleoclimates enables us to improve and better constrain climate models in order to forecast future climate variations. Marine Isotope Stage 11 (MIS11), which began around 425,000 yr BP and lasted about 65,000 yr, is a warm isotope stage of paramount importance, because the astronomical configuration was similar to the one characterizing the Holocene. Therefore, this warm isotope stage is the most appropriate analog to present-day climate known to date. This study aims to provide new data on sea-surface temperatures (SSTs) inferred from the carbon and oxygen isotope compositions of skeletal carbonates of marine invertebrates preserved in two marine deposits of the Canary Islands located at Piedra Alta, Lanzarote, and Arucas, Gran Canaria. According to published isotopic fractionation equations the marine deposit from Arucas recorded SSTs of $15.9 \pm 2.2^{\circ} \mathrm{C}$ on average, while the tsunamite from Piedra Alta recorded SSTs of $21.2 \pm 1.9^{\circ} \mathrm{C}$ on average. Absolute dating, mollusc assemblages, and calculated marine temperatures suggest that the Arucas marine deposit corresponds to the beginning of MIS11, while the Piedra Alta tsunamite was formed during MIS11c. These results show that low latitudes also experienced sizable SST changes during interglacial stages.

Keywords: Stable isotope; Sea-surface temperature; Tsunami; Mollusc; Canary archipelago; MIS11; Climate change

\section{INTRODUCTION}

The fifth assessment report of the Intergovernmental Panel on average mean annual temperatures of $+0.85^{\circ} \mathrm{C}$ between 1880 and 2012, each decade being warmer than the previous one. This increase in temperature, associated with the melting of the northern ice cap and the rise of global sea level, constitutes the central concern of global climate change. Consequently, there is a need to predict the evolution of global climate through the use of numerical models ranging from simple energy-balance models to complex Earth system models (Flato et al., 2013). Paleoclimatic data obtained from various proxies coming from sedimentary archives of interglacial stages are necessary to affix boundary conditions to such numerical models.

$\S$ Also at Institut Universitaire de France, Paris, France.

Cite this article: Clauzel, T., Maréchal, C., Fourel, F., Barral, A., Amiot, R., Betancort, J.-F., Lomoschitz, A., Meco, J., Lécuyer, C. 2019. Reconstruction of sea-surface temperatures in the Canary Islands during Marine Isotope Stage 11. Quaternary Research 1-15. https://doi.org/ 10.1017/qua.2019.65 Climate Change (IPCC, 2014) reported a global increase in
Paleontological, geochemical, and sedimentological records reveal climate variations between cold and warm stages for the last $3 \mathrm{Ma}$. For the last million year, since the mid-Pleistocene transition (Medina-Elizalde and Lea, 2005), the cold stages lasted around 100,000 yr. The glacial and interglacial stages of the last million years, which are called Marine Isotope Stages (MIS), arouse much interest (e.g., Augustin et al., 2004; Tzedakis, 2010; Robinson et al., 2017), because they could contribute to our understanding of the climate dynamics of the Holocene (MIS1) and, especially, the evolution of an interglacial stage devoid of any anthropic influence and its consequent impact upon ecosystems and coastal geomorphology. Many studies have been devoted to two interglacial stages, MIS5e (Oppo et al., 2006; Jouzel et al., 2007) and MIS11c, the latter being usually considered as the best analog to Holocene climate change (Droxler et al., 2003; Loutre and Berger, 2003). Indeed, MIS11 and MIS1 share the same configuration of orbital parameters: low eccentricity, low precession, and weak variations in insolation. MIS11c, which is an interglacial stage within the MIS11 warm isotope stage, lasted a long time (around $27,000$ to $30,000 \mathrm{yr})$ compared with other interglacial stages such as MIS9e $(\approx 12,000$ yr $)$ and MIS5e $(\approx 13,000$ yr $)$ 
according to Shackleton (1967), Howard (1997), McManus et al. (2003), Augustin et al. (2004), and Prokopenko et al. (2010). Candy et al. (2014) performed a global review of the climate characteristics of the MIS11 warm isotope stage. In the framework of our study, it is worth noting that the record of $\delta^{2} \mathrm{H}$ in ice cores of Dome $\mathrm{C}$ in Antarctica $\left(75^{\circ}\right.$ $06^{\prime} \mathrm{S}, 123^{\circ} 20^{\prime} \mathrm{E}$ ) (Augustin et al., 2004; Jouzel et al., 2007) indicates that the air temperature optimum during MIS11c was around $3^{\circ} \mathrm{C}$ higher than today, although this surface temperature change refers to the high latitudes of the Northern Hemisphere and is higher than the global mean temperature change. The study of raised beaches located in tectonically stable regions and of ice cap dynamics during MIS11 revealed that the sea level was 6 to $13 \mathrm{~m}$ higher than today on average (de Vernal and Hillaire-Marcel, 2008; Elderfield et al., 2012; Roberts et al., 2012). Moreover, the analysis of terrestrial records corresponding to MIS11 has shown that this warm isotope stage was globally humid (Rousseau, 2003; Prokopenko et al., 2010; Melles et al., 2012). The configuration of astronomical parameters during MIS11, especially the weak precession, induced weaker insolation variability than for other warm isotope stages (Berger and Loutre, 2002). Consequently, MIS11 is a warm isotope stage that is tricky to detect and quantify in the geologic record, as reflected in the relative lack of data for this stage compared with other marine isotope stages such as MIS5.

Here we provide measurements of the stable carbon and oxygen isotope ratios of skeletal carbonates from marine invertebrates sampled from two marine sequences from the Canary Islands that were deposited during MIS11. The oxygen isotope ratios are then used to calculate sea-surface temperatures (SSTs) using an oxygen isotope fractionation equation for the aragonite-water system. During the two periods of MIS11 studied, SSTs within tropical latitudes in the eastern Atlantic Ocean bracketed those documented during the present day, although the magnitude of seasonal variation was most likely weaker than at present.

\section{GEOLOGIC SETTING AND MATERIAL STUDIED}

The Canary archipelago is composed of seven volcanic islands located in the eastern Central Atlantic Ocean between $27^{\circ} \mathrm{N}$ and $30^{\circ} \mathrm{N}$, west of Morocco (Fig. 1a). The formation of the archipelago is linked to the movement of the African plate over a magmatic hot spot (Carracedo et al., 1998). Lanzarote, Fuerteventura, and Gran Canaria, the easternmost and oldest islands, share an arid and warm climate resulting from their latitudinal position, their orography, and their proximity to the Sahara Desert. El Hierro and La Palma, the westernmost and youngest islands, are under the influence of the humid northeast trade winds. Different methods have been used to estimate present-day mean annual temperatures (MATs) and SSTs for low latitudes such as $28^{\circ} \mathrm{N}$. Borges et al. (2004) analyzed time series of the southeastern North Atlantic sea surface obtained from the Advanced Very High Resolution
Radiometer (AVHRR) and estimated an average SST close to $20.5^{\circ} \mathrm{C}$. Comparable average SSTs close to $20.3^{\circ} \mathrm{C}$ were published by DeCastro et al. (2014) for the Moroccan subregion during the period 1982-2012. Such temperature estimates have been based on the National Oceanic and Atmospheric Administration's (NOAA) high-resolution analyses of daily SST. Gómez-Letona et al. (2017) estimated a SST of $20.3^{\circ} \mathrm{C}$ for the coastal waters of the Canary archipelago, using daily Reynolds analyses that combine AVHRR and in situ data. The Climate Atlas of the Spanish Met service (AEMET, 2012) indicates a MAT of $20^{\circ} \mathrm{C}$ for the Gran Canaria and Lanzarote islands. These temperatures are relatively low compared with those prevailing in the western part of the central Atlantic Ocean, such as the Caribbean Islands, which have temperatures close to $27^{\circ} \mathrm{C}-29^{\circ} \mathrm{C}$ (Winter et al., 1998). Such low temperatures around the Canary archipelago are explained by the presence of a southward-flowing oceanic current, called the Canary Current, originating from the eastern boundary current of the subtropical North Atlantic gyre that is located along the northwest African coast. The current splits as it passes the Canary archipelago, with branches located east and west of Lanzarote. It is associated with a strong coastal upwelling regime along the northwest African coast, caused by the northeast trade winds. The coastal upwelling is permanent at a latitude of $28^{\circ} \mathrm{N}$, with its strongest activity occurring in summer and early fall, which results in lower SSTs over the shelf (Navarro-Pérez and Barton, 2001; Pardo et al., 2011).

Marine sedimentary deposits of Quaternary age crop out along the coasts of several islands in the Canary archipelago, namely Lanzarote, Fuerteventura, Gran Canaria, and Tenerife (Muhs et al., 2014; Meco et al., 2018). This study focuses on two marine deposits attributed to MIS11, the first one being located on Arucas (Gran Canaria) and the second one being located in Piedra Alta (Lanzarote).

The first marine deposit crops out at Arucas on the northern side of the island of Gran Canaria $\left(28^{\circ} 08^{\prime} \mathrm{N}, 15^{\circ} 29^{\prime} \mathrm{W}\right.$; Figs. $1 \mathrm{~b}$ and 2a). First described by Benítez (1912), this sedimentary sequence extends to about $2 \mathrm{~km}$ in length from east to west and is deposited above a tephritic basaltic flow including some pillow lavas, most likely related to the former activity of the Cardones volcano. This lava flow was dated by the K-Ar method at $421 \pm 20 \mathrm{ka}$ (Meco et al., 2002). This K-Ar age allowed Meco et al. (2002) to correlate this marine deposit with MIS11. Today, the base of the Arucas deposit crops out about $30 \mathrm{~m}$ above sea level as a result of a westward tilting of Gran Canaria, linked to the lithospheric flexure exerted by the growth of the younger island of Tenerife (Perez-Torrado et al., 2002; Menéndez et al., 2008; Meco et al., 2011). An extralimital species such as Saccostrea cuccullata (Ostreidae) occurs in this deposit and suggests that SSTs were at least $4.2^{\circ}$ $\mathrm{C}$ higher than those prevailing at present according to Montesinos et al. (2014).

The second marine deposit included in this study is exposed on the southwest part of the island of Lanzarote $\left(28^{\circ} 53^{\prime} \mathrm{N}, 13^{\circ} 51^{\prime} \mathrm{W}\right.$; Figs. $1 \mathrm{c}$ and $\left.2 \mathrm{~b}\right)$. First described by Driscoll et al. (1965), it crops out over $2 \mathrm{~km}$ along the coast and at 


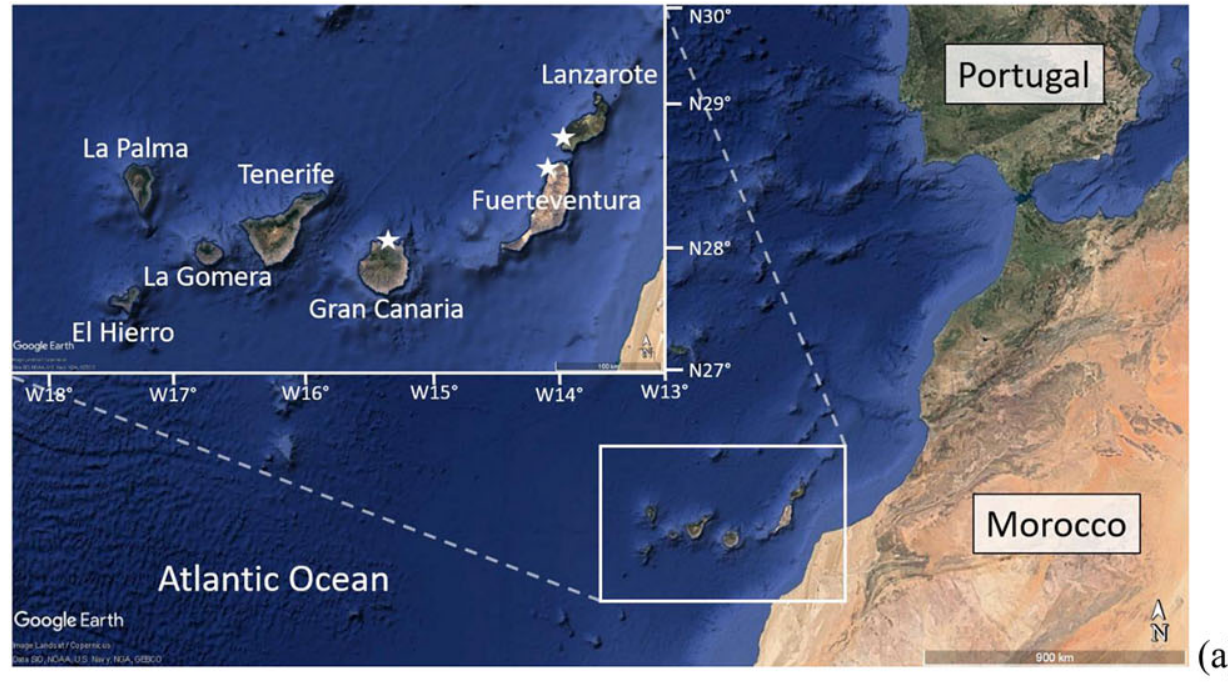

(a)

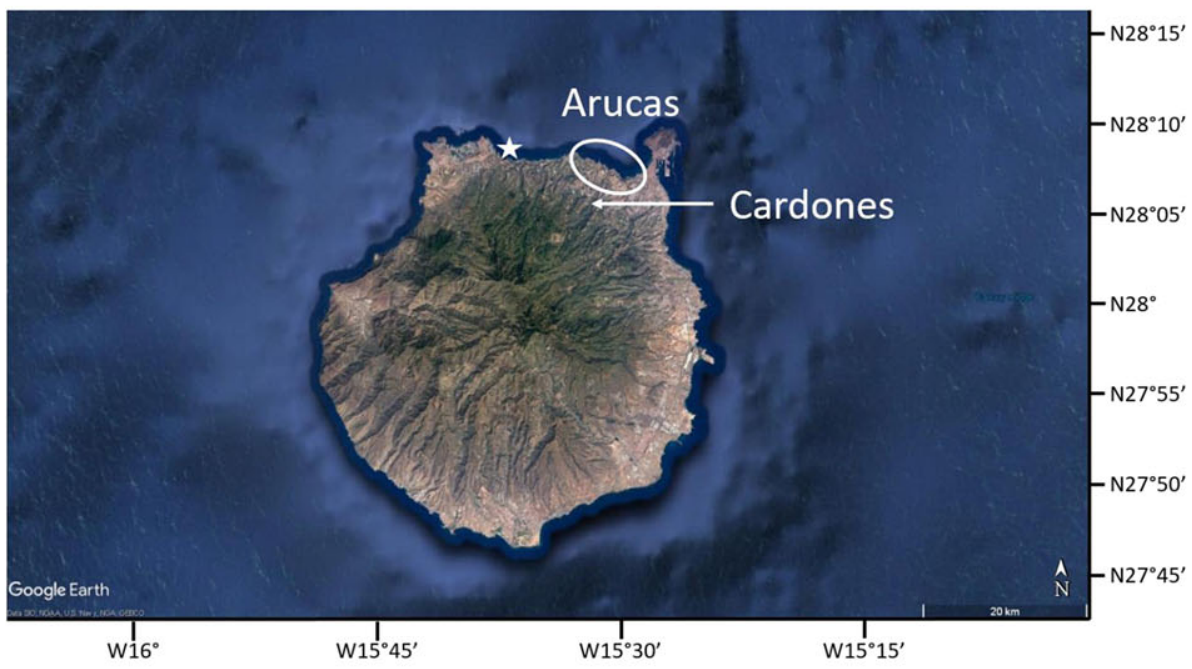

(b)

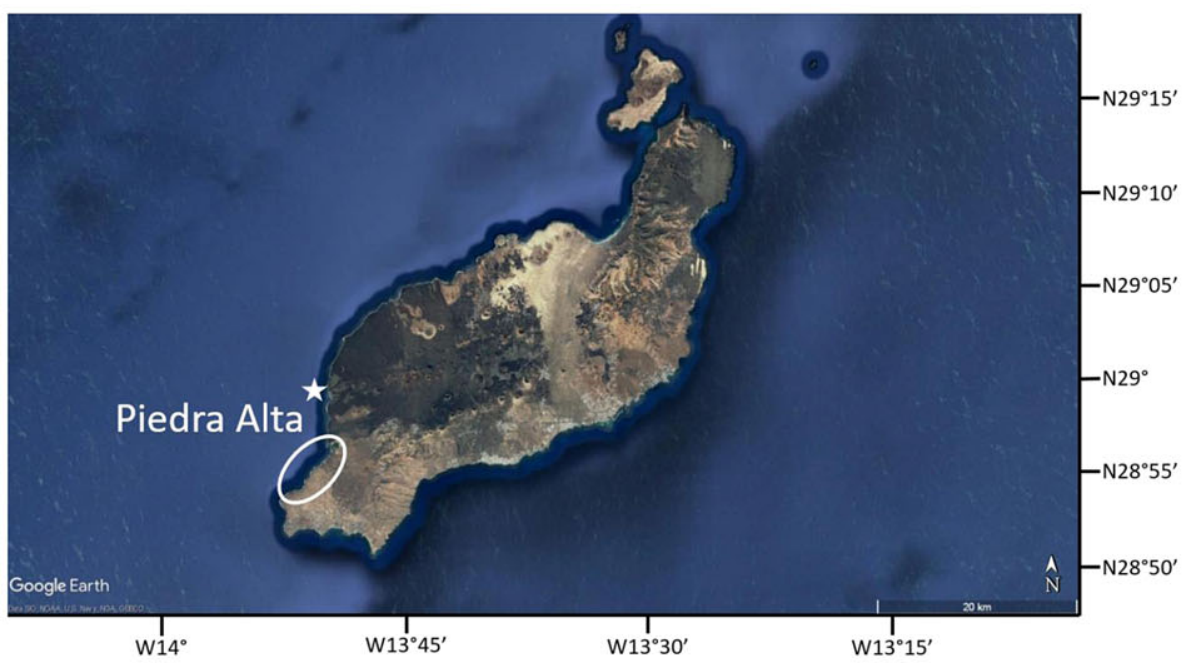

(c)
Figure 1. (color online) (a) Location of the Canary archipelago in the Atlantic Ocean; (b) Gran Canaria island, with the location of the Arucas marine deposit circled; and (c) Lanzarote island, with the location of the Piedra Alta tsunamite circled. The locations where coastal waters were sampled are represented by white stars. The datum used for latitude and longitude is WGS84. Pictures were taken from Google Earth. 
(a)
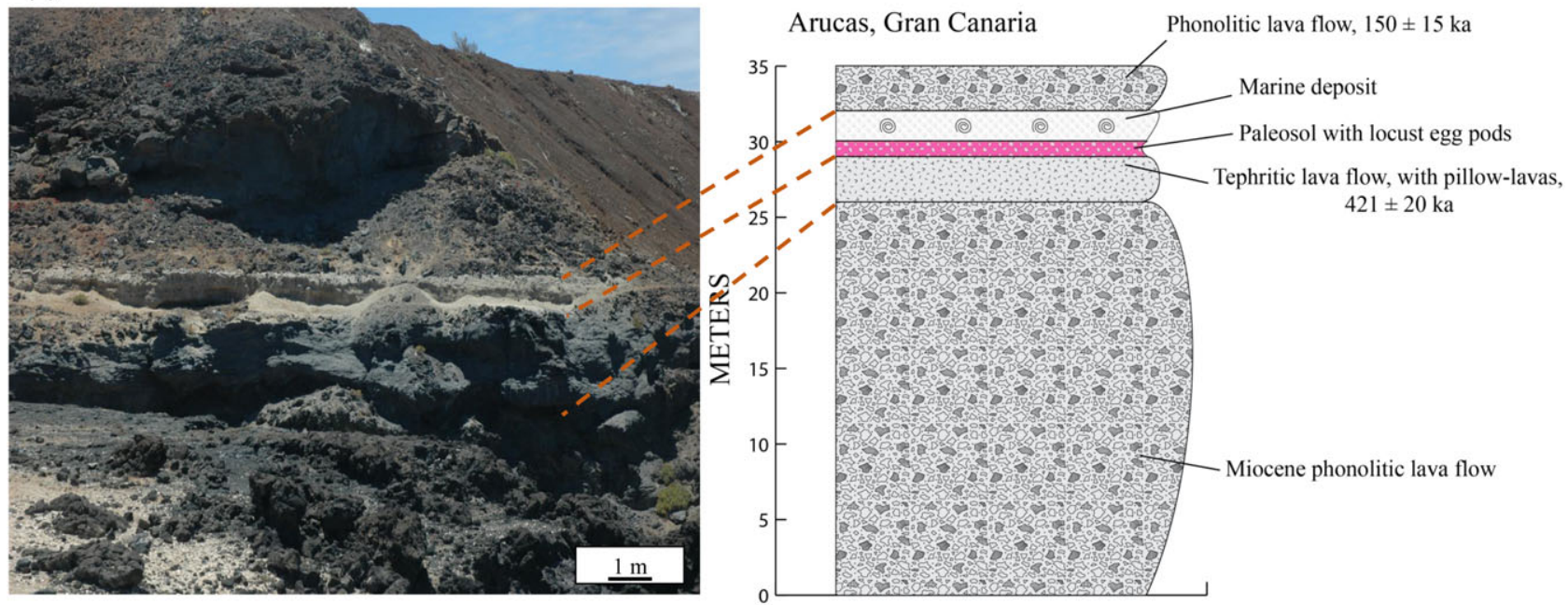

(b)

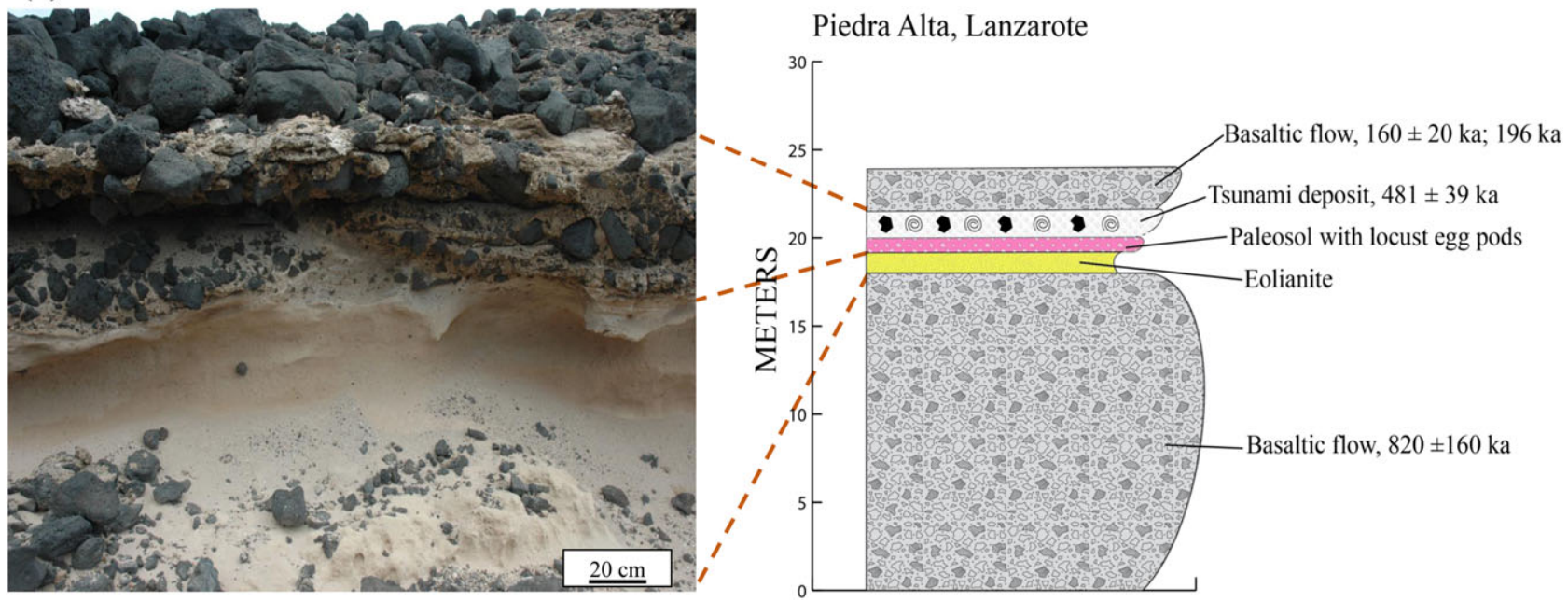

Figure 2. (color online) The Arucas marine deposit (a) and the Piedra Alta tsunamite (b) and their geologic interpretation with stratigraphic logs. Modified after Muhs et al. (2014) and Meco et al. (2011).

least $7 \mathrm{~km}$ inland, while the base of the deposit occurs $20 \mathrm{~m}$ above the present-day sea level. Zazo et al. (2002) attributed the marine deposit to the Episode IX of their raised marine sequences with a sea level 8 to $10 \mathrm{~m}$ higher than today. In terms of chronology, they correlated this marine deposit to MIS11 (Zazo et al., 2002). The marine deposit is interlayered between two basaltic flows that were dated by K-Ar at $820 \pm$ $160 \mathrm{ka}$ for the bottom flow (Meco and Stearns, 1981), while two ages were proposed for the top flow: $160 \pm 20$ ka by Zazo et al. (2002) and more recently $196 \mathrm{ka}$ by Meco et al. (2011). The marine deposit is poorly sorted, consists of abundant angular or subangular basaltic boulders, and includes large metric basalt boulders as well as finer-grained volcanic clasts. Some of the basaltic clasts are covered by a layer of marine sandstones, while the boulders are cemented with reddish limestones, generally rich in clays (Meco et al., 2008). The sedimentary matrix is very fossiliferous, with abundant remains of marine invertebrate shells, none of which were observed in life position. Meco et al. (2008) noticed that the marine deposit contains a mixture of species with different ecology, such as the genus Patella, which is typical of the intertidal zone; species like Gadinia garnoti, which are intertidal and live in the high-tide zone; and fragments of the infralittoral coral Madracis pharencis and the circalittoral (at depths greater than $50 \mathrm{~m}$ ) gastropod Bursa tenuisculpta.

These paleontological and sedimentological features allowed Meco et al. (2008) to consider that this deposit was not formed by a slow process of continuous sedimentation but rather by an instantaneous and catastrophic event at the geologic scale, such as a tsunami deposit, like the previously identified Agaete tsunami conglomerate in Gran Canaria and the northwestern coast of Tenerife (Paris et al., 2017, 2018).

We selected 64 specimens of marine invertebrates from the Piedra Alta deposit and 77 specimens from the Arucas deposit for carbon and oxygen isotope measurements of the invertebrate marine fauna contemporaneous with MIS11 (see Table 1). In both cases, the faunal assemblage is composed of several species of molluscs, echinoderms, cnidarians, and bryozoans, whose habitats are infralittoral to intertidal and for which the taxonomy is reported in Table 1. 
Table 1. Specimens collected from the Piedra Alta tsunamite and the Arucas marine deposit. The habitats data are extracted from Meco et al. (2008).

\begin{tabular}{|c|c|c|c|c|c|}
\hline \multicolumn{6}{|l|}{ Piedra Alta tsunamite } \\
\hline Taxon & Sample & Phylum & Class & Living environment & Number of specimens \\
\hline Patella depressa & PA-01 & Mollusca & Gastropoda & Intertidal & 4 \\
\hline Patella aspera & PA-02 & Mollusca & Gastropoda & Intertidal & 5 \\
\hline Bolma rugosa & PA-03 & Mollusca & Gastropoda & Infralittoral & 11 \\
\hline Turritella ligar & PA-04 & Mollusca & Gastropoda & Infralittoral & 7 \\
\hline Conus vayssieri & PA-05 & Mollusca & Gastropoda & Infralittoral & 5 \\
\hline Glycymeris glycymeris & PA-06 & Mollusca & Bivalvia & Infralittoral & 4 \\
\hline Hyotissa hyotis & PA-08 & Mollusca & Bivalvia & Infralittoral & 9 \\
\hline Saccostrea cuccullata & PA-09 & Mollusca & Bivalvia & Infralittoral & 8 \\
\hline Callista chione & PA-10 & Mollusca & Bivalvia & Infralittoral & 5 \\
\hline Madracis pharensis & PA-11 & Cnidaria & Anthozoa & Infralittoral & 2 \\
\hline Smittina cervicornis & PA-13 & Bryozoa & Gymnolaemata & Infralittoral & 2 \\
\hline Cidaris sp. & PA-14 & Echinodermata & Echinoida & Infralittoral & 2 \\
\hline \multicolumn{6}{|l|}{ Arucas marine deposit } \\
\hline Saccostrea cuccullata & ARU-01 & Mollusca & Bivalvia & Infralittoral & 3 \\
\hline Stramonita haemastoma & ARU-02 & Mollusca & Gastropoda & Infralittoral & 5 \\
\hline Cerithium rupestre & ARU-03 & Mollusca & Gastropoda & Infralittoral & 10 \\
\hline Bolma rugosa & ARU-04 & Mollusca & Gastropoda & Infralittoral & 1 \\
\hline Tectarius striatus & ARU-05 & Mollusca & Gastropoda & Infralittoral & 5 \\
\hline Diodora gibberula & ARU-06 & Mollusca & Gastropoda & Intertidal & 4 \\
\hline Vermetus triquetrus & ARU-07 & Mollusca & Gastropoda & Infralittoral & 4 \\
\hline Charonia lampas & ARU-08 & Mollusca & Gastropoda & Infralittoral & 3 \\
\hline Patella aspera & ARU-09 & Mollusca & Gastropoda & Intertidal & 4 \\
\hline Nucella lapillus & ARU-10 & Mollusca & Gastropoda & Intertidal & 4 \\
\hline Cardita calyculata & ARU-11 & Mollusca & Bivalvia & Intertidal & 4 \\
\hline Columbella rustica & ARU-12 & Mollusca & Gastropoda & Infralittoral & 5 \\
\hline Bursa scrobiculator & ARU-13 & Mollusca & Gastropoda & Infralittoral & 2 \\
\hline Tritia pfeifferi & ARU-14 & Mollusca & Gastropoda & Infralittoral & 3 \\
\hline Vexillum zebrinum & ARU-15 & Mollusca & Gastropoda & Intertidal & 3 \\
\hline Phorcus turbinatus & ARU-16 & Mollusca & Gastropoda & Intertidal & 4 \\
\hline Phorcus lineatus & ARU-17 & Mollusca & Gastropoda & Intertidal & 3 \\
\hline Cerithium vulgatum & ARU-18 & Mollusca & Gastropoda & Infralittoral & 2 \\
\hline Patella vulgata & ARU-19 & Mollusca & Gastropoda & Intertidal & 4 \\
\hline Paracentrotus lividus & ARU-20 & Echinodermata & Echinoida & Infralittoral & 4 \\
\hline
\end{tabular}

\section{ANALYTICAL TECHNIQUES}

Skeletons of marine invertebrates are mainly composed of either calcite or aragonite. Preservation of the initial mineralogy in a fossil is largely dependent on the temperaturesensitive solubility of these polymorphs in an aqueous phase. Indeed, at $25^{\circ} \mathrm{C}$, the solubility products $\left(\mathrm{K}_{\mathrm{sp}}\right)$ are quite high, with values of $10^{-8.48}$ and $10^{-6.40}$ for calcite and aragonite, respectively, according to data from the National Institute of Standards and Technology-Joint Army Navy NASA Air Force (NIST-JANAF) thermodynamic tables (Chase, 1998). Consequently, because aragonite is less stable than calcite, it cannot be excluded that calcitic shells were aragonitic in origin before being diagenetically altered into secondary calcite. It has been known for decades (Land, 1967) that recrystallization operates at ambient temperature in the presence of water during the burial of fossils. Those aqueous fluids may be pore waters, in the case of early diagenesis, or crustal waters of meteoric or metamorphic origin during late diagenesis.

\section{Raman spectroscopy}

We used Raman spectroscopy to characterize the mineralogy of all the skeletal carbonates studied. The two polymorphs of $\mathrm{CaCO}_{3}$ are readily identified from the low-frequency part of the spectra, and especially from the position and splitting of the symmetric bending mode, which occurs as a single peak at $712 \mathrm{~cm}^{-1}$ in calcite and as a doublet at $701-704 \mathrm{~cm}^{-1}$ in aragonite (e.g., Unvros et al., 1991; Gillet et al., 1993). The Raman Spectrometer X'plora, hosted by the Laboratoire de Géologie de Lyon at the University Claude Bernard Lyon 1 , was operated using a $1000 \times$ objective, an optical network of 1800 lines per $\mathrm{mm}$, a monochromatic laser $(532 \mathrm{~nm}$ wavelength) filtered by $10 \%$ with two acquisitions ( $60 \mathrm{~s}$ per acquisition) performed between 100 and $1600 \mathrm{~cm}^{-1}$.

\section{Sampling strategy}

Macroscopic criteria to select the skeletal carbonates for the measurement of stable isotope ratios are unbroken shells, 
the absence of mechanical erosion, and dissolution patterns. The selected skeletal carbonates were cleaned by repeated washing with deionized water in an ultrasonic bath to remove any remaining sedimentary particles. For most skeletal carbonates, we performed bulk analysis (hereafter "bulk" protocol), which consists, after mechanically removing the most juvenile parts of the shells (i.e., the umbo area), of powdering the remaining shells in an agate mortar. The juvenile parts are removed because they are biased by a kinetic fractionation linked to the fast growth of the shell at that moment. For two molluscs, Callista chione from Piedra Alta (PA-10-04) and Cerithium vulgatum from Arucas (ARU-18-02), shells were incrementally sampled with a Dremel micro-drill (hereafter "incremental" protocol) along the main growth axis from the apex of the shell to the aperture to measure the ontogenetic evolution of their carbon and oxygen isotope ratios.

\section{Carbon and oxygen isotope analysis of skeletal carbonates}

The carbonate analyses were carried out at the Laboratoire d'Écologie des Hydrosystèmes Naturels et Anthropisés (LEHNA) in Lyon using an isoFLOW system connected online in continuous-flow mode to a precisION mass spectrometer operated by visION software from Elementar UK Ltd. Sample powders were loaded in LABCO Exetainer 3.7 $\mathrm{mL}$ round-bottomed, nonevacuated soda-glass vials. For pure carbonate samples, aliquots of 300 to $500 \mu \mathrm{g}$ for the bulk protocol and aliquots of $15 \mu \mathrm{g}$ for the incremental protocol were reacted with anhydrous phosphoric acid prepared according to the protocol described by McCrea (1950). Phosphoric acid was automatically introduced in contact with the sample by the use of an acid pump. The reaction took place at $70^{\circ} \mathrm{C}$ in a temperature-regulated sample tray. The $\mathrm{CO}_{2}$ gas generated during the acid digestion of the carbonate sample was then transferred to the mass spectrometer via the centrION interface. A calibrated $\mathrm{CO}_{2}$ gas was used as a monitoring gas. An acid fractionation factor $\alpha\left(\mathrm{CO}_{2-}\right.$ -aragonite) of 1.0085 was selected according to Kim et al. (2007a). The calibrated material used was Carrara marble $\left(\delta^{18} \mathrm{O}_{\mathrm{VPDB}}=-1.84 \%\right.$; $\delta^{13} \mathrm{C}_{\mathrm{VPDB}}=+2.03 \%$ ) (Fourel et al., $2016)$ and NBS18 $\left(\delta^{18} \mathrm{O}_{\mathrm{VPDB}}=-23.2 \% ; \quad \delta^{13} \mathrm{C}_{\mathrm{VPDB}}=\right.$ -5.01\%o) (Friedman et al., 1982; Hut, 1987; Stichler, 1995; Coplen et al., 2006). Aliquots of Carrara marble were placed at the beginning and at the end of each analytical batch to correct for potential instrument drift through time. Delta values are expressed with respect to VPDB. External reproducibility $(2 \sigma)$ was lower than $\pm 0.1 \%$ for $\delta^{18} \mathrm{O}$ and $\pm 0.05 \%$ for $\delta^{13} \mathrm{C}$.

\section{Oxygen isotope analysis of water}

Coastal marine waters (1-5 m depth) were sampled along the coasts of Lanzarote (Piedra Alta, one sample), Fuerteventura (two samples), and Gran Canaria (Arucas, one sample), as depicted in Figure 1. The ${ }^{18} \mathrm{O} /{ }^{16} \mathrm{O}$ analyses from water samples were carried out at the LEHNA in Lyon using an isoFLOW system in water equilibration mode (Epstein and Mayeda, 1953; Horita et al., 1989; McCarthy et al., 2005) connected online in continuous-flow mode to a precisION mass spectrometer operated by a visION software from Elementar UK Ltd. Aliquots $(200 \mu \mathrm{L})$ were loaded in LABCO Exetainer $3.7 \mathrm{~mL}$ round-bottomed, nonevacuated soda-glass vials. The sample vial headspace was automatically flushed with helium with the isoFLOW double-needle setup. The equilibration gas was a mixture of $10 \% \mathrm{CO}_{2}$ in helium automatically introduced in contact with the sample through the isoFLOW. The equilibration reaction took place at $40^{\circ} \mathrm{C}$ in a temperature-regulated sample tray. The equilibrated $\mathrm{CO}_{2}$ gas generated was then transferred to the mass spectrometer via the centrION interface. A calibrated $\mathrm{CO}_{2}$ gas was used as a monitoring gas. Calibrated waters were used to anchor the results to the V-SLAP/V-SMOW scale. The calibrated waters used were EdL III $\left(\delta^{18} \mathrm{O}_{\mathrm{VSMOW}}=-9.34 \%\right.$ ), EE1 $\left(\delta^{18} \mathrm{O}_{\text {VSMOW }}=+6.442 \% o\right)$, and SSRW $\left(\delta^{18} \mathrm{O}_{\text {VSMOW }}=\right.$ $-16.0 \%$ ). During the course of the experiments, the waters used as working standards were calibrated against waters from the Water Isotope Inter-Comparison intercalibration program (Wassenaar et al., 2018). Aliquots of EdL III were placed at the beginning and at the end of each analytical batch to correct for potential instrument drift with time. Delta values are expressed with respect to VSMOW. Typical external precision for $\delta^{18} \mathrm{O}$ analyses from water samples is $0.05 \%$. Samples were systematically duplicated. When necessary, in the case of oxygen isotope ratios, a correction of $-0.27 \%$ was applied to convert $\delta^{18} \mathrm{O}$ of water from the VSMOW to VPDB scales according to Hut (1987). This correction is necessary to compare measured $\delta^{18} \mathrm{O}$ of $\mathrm{CO}_{2}$ produced by the reaction of the carbonate with $\mathrm{H}_{3} \mathrm{PO}_{4}$ and the $\mathrm{CO}_{2}$ equilibrated with $\mathrm{H}_{2} \mathrm{O}$.

\section{Calculation of SST for the marine deposits}

The SSTs were calculated using an oxygen isotope fractionation equation for the aragonite-water system. Two main equations were available for this calculation. The first one (Grossman and $\mathrm{Ku}, 1986$ ) was determined by analyzing modern molluscs and ambient water in the temperature range $\approx 3^{\circ}$ $\mathrm{C}-15^{\circ} \mathrm{C}$ with $\delta^{18} \mathrm{O}_{\text {aragonite }}\left(\delta^{18} \mathrm{O}_{\mathrm{ar}}\right)$ and $\delta^{18} \mathrm{O}_{\text {seawater }}\left(\delta^{18} \mathrm{O}_{\mathrm{sw}}\right)$ relative to VPDB:

$$
T=20.6-4.34\left({ }^{18} \mathrm{O}_{\mathrm{ar}}-{ }^{18} \mathrm{O}_{\mathrm{sw}}\right)
$$

The second oxygen isotope fractionation equation (Kim et al., 2007a, 2007b) was obtained from laboratory experiments with $\delta^{18} \mathrm{O}_{\mathrm{ar}}$ and $\delta^{18} \mathrm{O}_{\mathrm{sw}}$ relative to VSMOW:

$$
1000 \ln _{\mathrm{ar}-\mathrm{sw}}=17.88\left(\frac{10^{3}}{T}\right)-31.14
$$

$T$ being the temperature in kelvins and $\alpha$ the oxygen fractionation coefficient between aragonite and water: 


$$
\alpha_{\mathrm{ar}-\mathrm{sw}}=\frac{\left({ }^{18} \mathrm{O} /{ }^{16} \mathrm{O}\right)_{a r}}{\left({ }^{18} \mathrm{O} /{ }^{16} \mathrm{O}\right)_{s w}}
$$

The errors associated with the linear regression of empirical data $(y=m x+b)$, which are not available in the original publications, have been computed as the mean standard error for the $y$ value and are $\pm 1.38^{\circ} \mathrm{C}$ for the Grossman and $\mathrm{Ku}$ (1986) equation and $\pm 1.15^{\circ} \mathrm{C}$ for the Kim et al. (2007a, 2007b) equation. SSTs calculated from the $\delta^{18} \mathrm{O}$ of modern mollusc shells and $\delta^{18} \mathrm{O}$ of ambient seawater in Crete, Greece, best match those available from oceanic databases available for the Mediterranean Sea when using the Kim et al. (2007a, 2007b) equation (Lécuyer et al., 2018). Grossman and $\mathrm{Ku}(1986)$ also acknowledged that their equation may overestimate temperature by about $2^{\circ} \mathrm{C}$. Therefore, we chose to use the Kim et al. (2007a, 2007b) equation to infer the SSTs that prevailed in the Canary Islands during MIS11.

\section{Correction of SST related to sea-level changes}

To correctly estimate the $\delta^{18} \mathrm{O}$ values of coastal seawaters in the Canary archipelago during MIS11, sea-level changes need to be taken into account. There is a long-standing debate about the sea-level range during MIS11. On the one hand, based on the study of raised shorelines in regions such as Bermuda (Hearty et al., 1999; Olson and Hearty, 2009) or the United Kingdom (Bowen, 2003), the high sea-stand levels are estimated to range from 10 to $15 \mathrm{~m}$ above modern sea levels and even up to $20 \mathrm{~m}$ above modern sea levels according to Roberts et al. (2012). On the other hand, authors of some modeling studies, those devoted to the Red Sea record in particular, argue that sea level during MIS11 was comparable to current sea level (Rohling et al., 2010). For more information about this debate, see Candy et al. (2014).

Muhs et al. (2014) calculated uplift rates for the Canary Islands by using the peak of the last interglacial period (LIG) and the dating of deposits from the LIG and proposed sea-level ranges associated with the different episodes of raised beaches in the Canary archipelago. Accordingly, based on a study of the Arucas deposit, Muhs et al. (2014) proposed a paleo-sea level of $+9 \mathrm{~m}$ to $+24 \mathrm{~m}$ relative to the present for Gran Canaria for MIS11. Muhs et al. (2014) also proposed a paleo-sea level of $+10 \mathrm{~m}$ to $+13 \mathrm{~m}$ relative to the present for Lanzarote, based on the Piedra Alta deposit, although the authors acknowledge being less confident concerning the latter estimate. Those two sea-level estimates are broadly consistent with each other and are similar to the range of sea-level estimates made for the island of Curaçao (Muhs et al., 2012). We chose to consider the average value of the MIS11 sea-level range for each marine deposit, which is included in the average paleo-sea level range attributed to MIS11 (de Vernal and Hillaire-Marcel, 2008; Elderfield et al., 2012; Roberts et al., 2012) and to integrate the range of uncertainty. Our final estimates correspond to sea- level ranges of $+16.5 \pm 7.5 \mathrm{~m}$ for the Arucas marine deposit and $+11.5 \pm 1.5 \mathrm{~m}$ for the Piedra Alta tsunamite. If we take an average $3700 \mathrm{~m}$ depth for the ocean (Charette and Smith, 2010) coupled to an average isotopic composition of the polar caps of $-40 \%$, a mass balance calculation indicates that a global sea-level rise of $+16.5 \pm 7.5 \mathrm{~m}$ would correspond to a decrease of seawater $\delta^{18} \mathrm{O}$ by $0.18 \pm 0.08 \%$, while a rise of $+11.5 \pm 1.5 \mathrm{~m}$ would correspond to a decrease of $0.12 \pm 0.02 \%$.

\section{RESULTS}

\section{Mineralogical composition of the shells studied}

All skeletal carbonates were analyzed by Raman spectroscopy to identify their mineralogy (Table 2). The inorganic fraction ( $>95 \%)$ of shells is entirely composed of either calcite or aragonite, with some exceptions, such as Patella depressa (PA-01), Stramonita haemastoma (ARU-02), Nucella lapillus (ARU-10), and Patella vulgata (ARU-19), which contain minute amounts $(<5 \%)$ of calcite. In the Piedra Alta tsunamite, the shell of Patella aspera (PA-02) is made of calcite, while in the Arucas marine deposit, the shell of the same species (ARU-09) is made of aragonite. As aragonite is the original mineralogy of the inner layer of the shell of Patella aspera (Parker et al., 2017), calcite is thus interpreted as an alteration product in the case of sample PA-02. Consequently, all the species fully composed of aragonite were selected for stable carbon and oxygen isotope analysis. Moreover, the species Saccostrea cuccullata (PA-09/ARU-01) was also selected for isotopic analysis, as it is present in both marine deposits in sufficient number to allow the isotopic values to be compared. However, as Saccostrea cuccullata is composed of calcite, the oxygen isotope ratios were not used to calculate the SST attributed to the marine deposits.

\section{Carbon and oxygen isotope compositions of skeletal carbonates}

The isotopic data are available in the Supplementary Material. For the Piedra Alta tsunamite, specimens have $\delta^{18} \mathrm{O}$ values ranging from $-1.40 \%$ to $1.60 \%$, with a mean value of $0.46 \%$, while $\delta^{13} \mathrm{C}$ values range from $-2.71 \%$ o to $2.95 \%$, with a mean value of $1.31 \%$. For the Arucas marine deposit, the $\delta^{18} \mathrm{O}$ values of skeletal carbonates are between $0.77 \%$ and $2.83 \%$, with a mean value of $1.55 \%$, while $\delta^{13} \mathrm{C}$ values are between $0.46 \%$ and $4.73 \%$, with a mean value of $2.42 \%$.

Two species, Callista chione from Piedra Alta (PA-10-04) and Cerithium vulgatum from Arucas (ARU-18-02), were sampled according to the incremental protocol. Callista chione has $\delta^{18} \mathrm{O}$ values ranging from $0.13 \%$ o to $0.79 \%$, with a mean value of $0.35 \%$, while $\delta^{13} \mathrm{C}$ values are between $0.02 \%$ and $1.90 \%$, with a mean value of $0.92 \%$. Cerithium vulgatum has $\delta^{18} \mathrm{O}$ values ranging from $0.11 \%$ o to $1.52 \%$, with a mean value of $1.07 \%$, while $\delta^{13} \mathrm{C}$ values are between $0.01 \%$ and $3.16 \%$, with a mean value of $1.98 \%$ o. In both cases, the $\delta^{13} \mathrm{C}$ and $\delta^{18} \mathrm{O}$ values show a pseudo-cyclic 
Table 2. Mineralogy of the biogenic carbonates interpreted from Raman spectra. The terms marked with an asterisk (*) specify that the mineralogy of the shell is mainly aragonitic with less than $5 \%$ being calcitic.

\begin{tabular}{|c|c|}
\hline Sample & Mineralogy of the shell \\
\hline PA-01 & Aragonite* \\
\hline PA-02 & Calcite \\
\hline PA-03 & Aragonite \\
\hline PA-04 & Aragonite \\
\hline PA-05 & Aragonite \\
\hline PA-06 & Aragonite \\
\hline PA-08 & Calcite \\
\hline PA-09 & Calcite \\
\hline PA-10 & Aragonite \\
\hline PA-11 & Aragonite \\
\hline PA-13 & Calcite \\
\hline PA-14 & Calcite \\
\hline ARU-01 & Calcite \\
\hline ARU-02 & Aragonite* \\
\hline ARU-03 & Aragonite \\
\hline ARU-04 & Aragonite \\
\hline ARU-05 & Aragonite \\
\hline ARU-06 & Aragonite \\
\hline ARU-07 & Aragonite \\
\hline ARU-08 & Aragonite \\
\hline ARU-09 & Aragonite \\
\hline ARU-10 & Aragonite* \\
\hline ARU-11 & Aragonite \\
\hline ARU-12 & Aragonite \\
\hline ARU-13 & Aragonite \\
\hline ARU-14 & Aragonite \\
\hline ARU-15 & Aragonite \\
\hline ARU-16 & Aragonite \\
\hline ARU-17 & Aragonite \\
\hline ARU-18 & Aragonite \\
\hline ARU-19 & Aragonite* \\
\hline ARU-20 & Calcite \\
\hline
\end{tabular}

variation recorded during the ontogenetic evolution of these two specimens studied. However, these isotopic ratios do not show any significant correlation in the case of Callista chione $\left(R^{2}=9 \times 10^{-4}\right)$, while they are significant in the case of Cerithium vulgatum $\left(R^{2}=0.52\right)$.

A few corrections have been applied to the isotopic values in some outliers. Like many corals, Madracis pharensis (PA-11) is ${ }^{18} \mathrm{O}$ - and ${ }^{13} \mathrm{C}$-depleted relative to coexisting molluscs. This isotopic pattern is related to the photosymbiotic relation between the coral and its zooxanthella (Land et al., 1975) and a kinetic isotope effect linked to a discrimination against ${ }^{18} \mathrm{O}$ and ${ }^{13} \mathrm{C}$ during the process of biomineralization, more precisely during the hydration and hydroxylation of $\mathrm{CO}_{2}$ (McConnaughey, 1989, 2003; Watkins et al., 2014). Therefore, we excluded the isotopic compositions of this coral sample from our data set. All the remaining specimens studied are molluscs, which are known to precipitate their shell carbonate close to carbon and oxygen isotope equilibrium with seawater (Grossman and Ku, 1986; Lécuyer et al., 2004, 2012). We also subtracted 1.01\%o from each $\delta^{18} \mathrm{O}$ value from Patella vulgata (ARU-19) to account for the predictable vital effect of the species (Wang et al., 2012).

Once we made these modifications to our database, $\delta^{18} \mathrm{O}$ values of mollusc shells range from $-0.26 \%$ to $1.60 \%$, with a mean value of $0.55 \%$, while the $\delta^{13} \mathrm{C}$ values are between $-0.28 \%$ and $2.95 \%$, with a mean value of $1.47 \%$ o for the Piedra Alta tsunamite. Concerning the Arucas marine deposit, $\delta^{18} \mathrm{O}$ values of mollusc shells range from $0.69 \%$ to $2.83 \%$, with a mean value of $1.49 \%$, while the $\delta^{13} \mathrm{C}$ values are between $0.46 \%$ and $4.73 \%$, with a mean value of $2.42 \%$. We also observed that the various mollusc species collected have clustered $\delta^{13} \mathrm{C}$ and $\delta^{18} \mathrm{O}$ values, which precludes any kind of identification of their distinct ecology within the littoral environment (Table 1).

\section{Oxygen isotope ratios of seawater samples}

The coastal marine waters sampled from Gran Canaria, Fuerteventura, and Lanzarote have $\delta^{18} \mathrm{O}$ values of $0.97 \pm 0.05 \%$, $1.08 \pm 0.07 \%$ (average between $1.09 \%$ and $1.06 \%$ ) , and $1.09 \pm 0.04 \%$ o, respectively. The values are quite homogenous among those islands, with a mean value of $1.05 \pm$ $0.07 \%$. The oxygen isotope ratios of coastal waters from Gran Canaria and Lanzarote have been corrected according to a higher sea level during MIS11 (see subsection "Correction of SST related to sea-level changes") and are $0.79 \pm$ $0.01 \%$ and $0.97 \pm 0.06 \%$, respectively.

\section{Calculation of the global uncertainty range}

There is a need to calculate a global uncertainty range integrating the several uncertainties produced by our calculations: the external reproducibility of the $\delta^{18} \mathrm{O}$ value of the skeletal carbonates $( \pm 0.1 \%$ o), errors associated with the linear regression of the oxygen isotope fractionation equations $\left( \pm 1.15^{\circ} \mathrm{C}\right.$ for the Kim et al. [2007a, 2007b] equation), and uncertainty linked to the correction for sea-level change during MIS11 $( \pm 0.06 \%$ or for the Piedra Alta marine deposit and $\pm 0.01 \%$ for the Arucas marine deposit). Consequently, for the SST at the Arucas marine deposit, the total uncertainty range is $\pm 1.4^{\circ} \mathrm{C}$ for the Kim et al. (2007a, 2007b) equation. For the SST recorded at the Piedra Alta tsunamite, the total uncertainty range is $\pm 1.5^{\circ} \mathrm{C}$ for the $\mathrm{Kim}$ et al. (2007a, 2007b) equation.

\section{SST calculated for the marine deposits}

The calculation of SST has been made using the oxygen isotope fractionation equation (Eq. 2) for the aragonite-water system: the data from shells composed of calcite (PA-09 and ARU-01) have been excluded from this calculation. For the 36 specimens analyzed from the Piedra Alta tsunamite (Fig. 3a), we calculated an average SST of $21.2 \pm 1.9^{\circ} \mathrm{C}$ according to Eq. 2. Similarly, for the 69 specimens analyzed from the Arucas marine deposit (Fig. 3b), we calculated an average SST of $15.9 \pm 2.2^{\circ} \mathrm{C}$ according to Eq. 2 . 
(a)

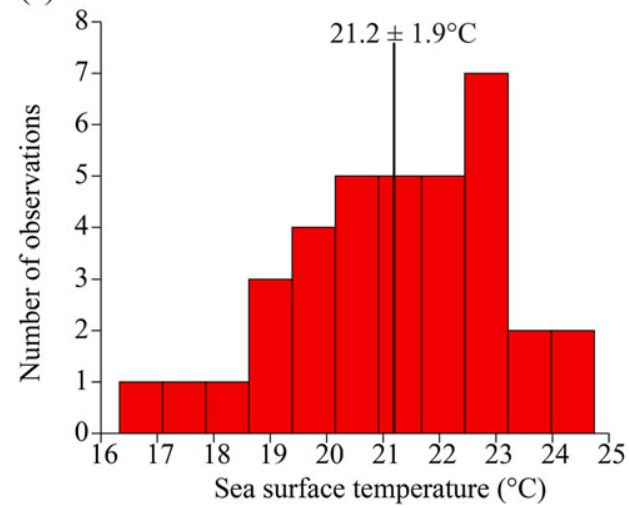

(b)

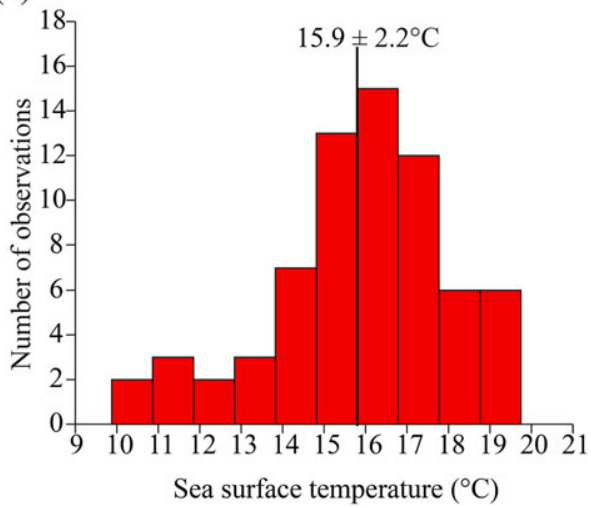

Figure 3. (color online) Distribution of MIS11 SSTs calculated by using the $\delta^{18} \mathrm{O}$ of aragonitic mollusc shells from (a) the Piedra Alta tsunamite with a $\delta^{18} \mathrm{O}_{\mathrm{sw}}$ value of $0.97 \%$ and (b) the Arucas marine deposit with a $\delta^{18} \mathrm{O}_{\text {sw }}$ value of $0.79 \%$. Those isotopic temperatures have been calculated according to the aragonite-water oxygen isotope fractionation equation given by Kim et al. (2007a, 2007b).

The ontogenetic profiles, calculated using Callista chione from Piedra Alta (PA-10-04) and Cerithium vulgatum from Arucas (ARU-18-02), reveal SST sinusoidal-like patterns that can be assigned to seasonal temperature variations (Fig. 4).

\section{DISCUSSION}

\section{Analysis of the SST calculated for the marine deposits}

We consider that the SST values calculated from a sample of the population of each marine deposit can be considered as representative of the SST of coastal waters during MIS11. In fact, there are no strong differences, in both marine deposits, between the carbon and oxygen isotope ratios recorded by intertidal and infralittoral species (see Table 1 and Supplementary Material). In addition to comparable standard deviations between the two populations of fossil molluscs from MIS11, the SST values follow a normal distribution according to the use of normal probability plots (executed with the software Past3) in which the correlation coefficients, $R^{2}$, are always higher than 0.98 (Filliben, 1975). This means that molluscan assemblages sampled from both the Piedra Alta and Arucas marine deposits correspond to coeval populations, representative of their habitats at a given moment. Such an observation is of paramount importance in the case of the Piedra Alta tsunamite, considering that this catastrophic marine deposit may have included several diachronous populations mixed and intercalated between the lava flows. In the case of the Arucas marine deposit, there may exist time averaging (hundreds or thousands of years) associated with the formation of the marine deposit, but the normal distribution of SSTs indicates that there are no major changes in the SST during this period, and that the values calculated are representative of the SST during MIS11 in the coastal waters of Gran Canaria. The SSTs calculated for the MIS11 are, in the case of Piedra Alta, comparable to the present SST in the
Canary archipelago. In the case of the Arucas marine deposit, the calculated SSTs are lower than present-day recorded SST.

These SST values are in good agreement with those obtained in the eastern Central Atlantic Ocean, such as ODP 958 , which ranges from $15^{\circ} \mathrm{C}$ to $20^{\circ} \mathrm{C}$ using various methods such as planktonic foraminiferal abundances, alkenone ratios, and oxygen isotope ratios of planktonic and benthic foraminifera (Helmke et al., 2008; Kandiano et al., 2012). They are also in agreement with the general idea that MIS11c was characterized by moderate warmth (Jouzel et al., 2007; Lawrence et al., 2009) compared with other interglacial episodes such as MIS5e (see Candy et al. [2014] for a comparison of SST records between MIS11 and MIS5).

The exoskeleton growth rates for most mollusc species follow a Von Bertalanffy growth mode (Von Bertalanffy, 1957) of the first order (Leveque, 1971; Cloern and Nichols, 1978). Thus, the signal recorded during shell growth is stretched during the juvenile age when the growth is fast, and it contracts when the growth slows down as the organism approaches maturity. Moreover, growth is also dependent on the temperature of ambient seawater. Shell growth may stop under and above some species-dependent threshold seawater temperatures. Consequently, the input signal resulting from the seasonal temperature variations, which is basically sinusoidal, is then distorted in the output oxygen isotope record, with maxima and minima being possibly truncated as the result of a lack of mineralization (Cornu et al., 1993). Such potential bias in the SST record at the seasonal scale implies that the calculated annual amplitude is most likely underestimated in most cases. We note that the seasonal amplitude in our study was between $3^{\circ} \mathrm{C}$ and $4^{\circ} \mathrm{C}$ and is weaker than the current seasonal seawater temperature variation, which is estimated to be around $6{ }^{\circ} \mathrm{C}$ in the Canary Islands (Borges et al., 2004).

Saccostrea cuccullata (PA-09/ARU-1; Table 1), which is an Ostreidae considered by Montesinos et al. (2014) as an extralimital species, occurs in both marine deposits. Those authors used Saccostrea cuccullata to propose that the SSTs in the Canary archipelago were at least $4.2^{\circ} \mathrm{C}$ higher 
(a)

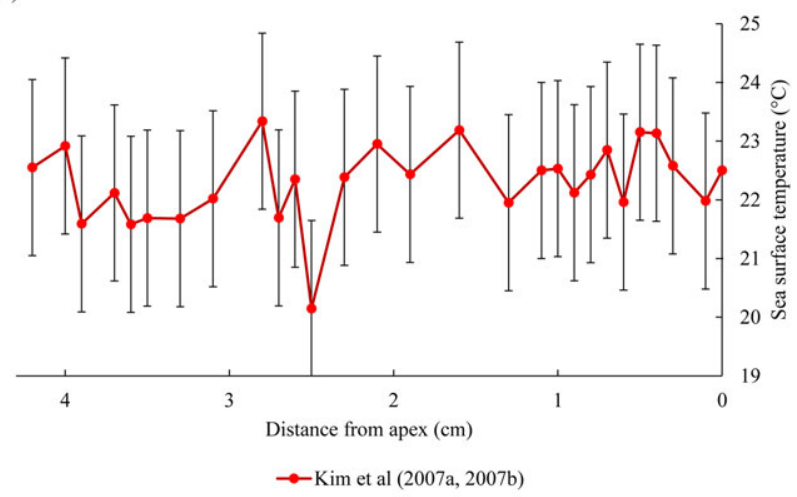

(b)

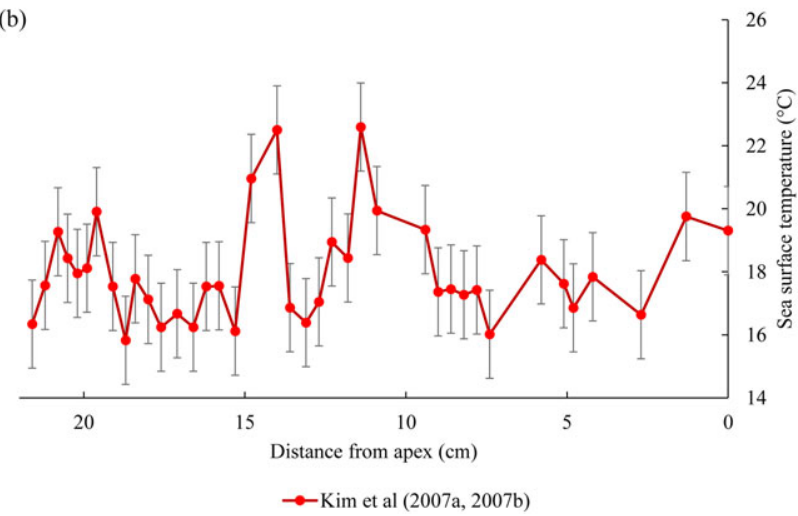

Figure 4. (color online) SST inferred from the incremental $\delta^{18} \mathrm{O}$ of aragonitic mollusc shells from (a) Callista chione (PA-10-04) and (b) Cerithium vulgatum (ARU-18-02), using the aragonite-water oxygen isotope fractionation equation determined by Kim et al. (2007a, 2007b).

during MIS11 than today. When Eq. 2 is applied to fossil mollusc shells from both marine deposits, we notice that our SST estimates are lower than those proposed by Montesinos et al. (2014). This means that Saccostrea cuccullata may be more tolerant to SST variations than previously thought and that this species might be able to live in colder environments.

\section{Dating of the marine deposits}

SSTs recorded in Arucas are around $5^{\circ} \mathrm{C}$ lower than those recorded in Piedra Alta and approximately $4^{\circ} \mathrm{C}$ lower than those measured during the last decades. The Arucas marine deposit is well dated, due to an interlayered basaltic flow dated by K-Ar at ca. $420 \mathrm{ka}$ (Meco et al., 2002, 2011). These dates need to be viewed in the light of the LR04 marine benthic $\delta^{18} \mathrm{O}$ stack record (Lisiecki and Raymo, 2005). The astronomical parameter configuration during MIS11 (low eccentricity, low precession, and low insolation variations) places both the insolation peak and the temperature peak during the middle of the warm isotope stage, that is, around 400 ka BP (Candy et al., 2014). Such relatively low temperatures recorded in Arucas would be in accordance with the deposition of marine sediments during the end of the Termination $\mathrm{V}$ between MIS12 and MIS11.
Muhs et al. (2014) dated the marine deposit of Piedra Alta by using the uranium series applied to fragments of the scleratinian coral Madracis pharensis, and they obtained an age of $481 \pm 39 \mathrm{ka}$, although a possible bias may be linked to an initial lack of ${ }^{234} \mathrm{U} /{ }^{238} \mathrm{U}$. According to Muhs et al. (2014), the Piedra Alta marine deposit could be correlated to either MIS11 or MIS13. However, the co-occurrence in the Piedra Alta tsunamite of the gastropods Patella depressa and Patella aspera, which have not been observed in the Canary archipelago before MIS11 and in the Mediterranean basin before the mid-Pleistocene (Meco et al., 2008), suggests that this deposit was more or less contemporaneous with MIS11. The occurrence of a similar paleosol (Fig. $2 \mathrm{a}$ and b) that contains innumerable fossilized egg pods from orthopters and terrestrial gastropods in both the Piedra Alta and Arucas marine deposits constitutes an argument to correlate them (Meco et al., 2011). These egg pods are usually linked to humid periods that correspond to the transitions between glacial and interglacial episodes in the Canary Islands (Meco et al., 2011). This paleosol is directly overlain by the tsunamite at Piedra Alta and by the marine deposit at Arucas (Meco et al., 2011). The paleo-sea level of $+10 \mathrm{~m}$ to $+13 \mathrm{~m}$ associated with the Piedra Alta tsunamite (Muhs et al., 2014) is also inconsistent with its correlation to MIS13, as most sea-level modeling outputs indicate the maximum sea level during MIS13 to have been about $16 \mathrm{~m}$ (Miller et al., 2005, 2011) to 28-30 m (Bintanja and Van de Wal, 2008) below present sea level. Moreover, the presence of species such as Saccostrea cuccullata and the SST values inferred from mollusc shells from Piedra Alta exclude its correlation with MIS13, which is considered a cold interglaciation, as witnessed by global air temperatures deduced from ice core isotopic records (Augustin et al., 2004; Jouzel et al., 2007) and SSTs calculated using the alkenone record in the Atlantic Ocean (Ho et al., 2012), which are consistently lower than SST values for MIS11 inferred from the study of marine sediments (Past Interglacials Working Group of PAGES, 2016).

Considering the absolute dating and the paleontological, sedimentological, and paleoclimatic data of the two marine deposits, we propose that the Piedra Alta deposit is younger than the Arucas deposit. This hypothesis is indeed in agreement with the absolute dating of the Arucas marine deposit at $421 \pm 20 \mathrm{ka}$ (Meco et al., 2002) and the SST values recorded in Piedra Alta mollusc shells, which are around $5^{\circ} \mathrm{C}$ higher than those calculated in Arucas. Consequently, the Piedra Alta marine deposit could correspond to the MIS11c interglacial stage, while the Arucas marine deposit could correspond to Termination $\mathrm{V}$, between MIS12 and MIS11 (Fig. 5).

\section{$\delta^{13} \mathrm{C}$ of marine species}

Carbon in the atmosphere is mostly present as carbon dioxide $\left(\mathrm{CO}_{2}\right)$, whereas more than $90 \%$ of the carbon in the deep ocean is present as bicarbonate $\left(\mathrm{HCO}_{3}^{-}\right)$, referred to as "dissolved inorganic carbon" (DIC). The reaction for 


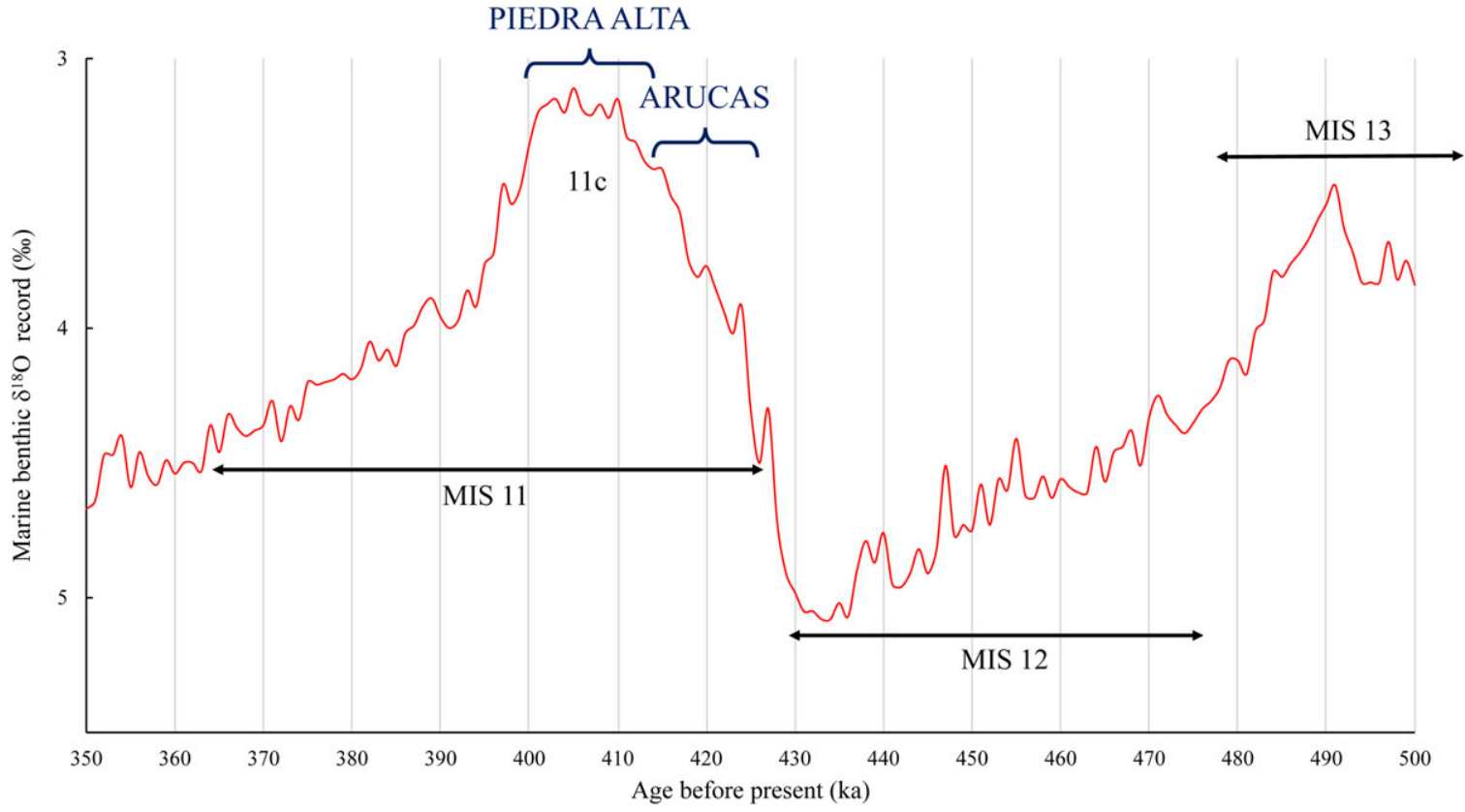

Figure 5. (color online) The LR04 marine benthic $\delta^{18} \mathrm{O}$ record normalized and plotted on the LR04 time scale, with the proposed chronology of the Piedra Alta tsunamite and the Arucas marine deposit with respect to MIS11, MIS12, and MIS13. After Lisiecki and Raymo (2005).

precipitation of carbonates in the seawater, known as the "carbonate pump," is:

$$
\mathrm{Ca}^{2+}+2 \mathrm{HCO}_{3}^{-} \leftrightarrow \mathrm{CaCO}_{3}+\mathrm{CO}_{2}+\mathrm{H}_{2} \mathrm{O}
$$

This chemical reaction involves little carbon isotopic fractionation compared with that taking place between carbon dioxide and bicarbonate ions, which constitute the main reservoir of DIC in the oceans. Thus, the $\delta^{13} \mathrm{C}$ of inorganically and biologically precipitated carbonate in the oceans is very close to that of DIC in the oceans (Maslin and Swann, 2006). The species Saccostrea cuccullata (PA-09/ARU-01) and Bolma rugosa (PA-03/ARU-04) are common in the two marine deposits studied (Table 1), even though the number of specimens analyzed is more important for the Piedra Alta tsunamite (11 specimens of Bolma rugosa and 8 specimens of Saccostrea cuccullata) than for the Arucas marine deposit (1 specimen of Bolma rugosa and 3 specimens of Saccostrea cuccullata). As only one specimen of Bolma rugosa from the Arucas marine deposit has been analyzed, which prevents a comparison between the two marine deposits, we compared the $\delta^{13} \mathrm{C}$ values of Saccostrea cuccullata for Piedra Alta and Arucas. This comparison allows us to dismiss the species-dependent carbon isotope fractionation between calcium carbonate and DIC. Consequently, a $\delta^{13} \mathrm{C}$ difference between the shells of Saccostrea cuccullata from the two marine deposits studied should represent a similar $\delta^{13} \mathrm{C}$ difference in seawater DIC of these marine deposits that could be attributed to a difference in interrelated variables: seawater temperature, the atmospheric $\mathrm{pCO}_{2}$, and the productivity of surface waters (Maslin and Swann, 2006). We observed that specimens of Arucas mollusc shells have $\delta^{13} \mathrm{C}$ values about
$0.6 \%$ higher on average than those present in Piedra Alta, which we consider to reflect a similar difference in the $\delta^{13} \mathrm{C}$ values of DIC of the Canary Islands coastal waters. Such an isotopic difference could be the consequence of SST being $6^{\circ} \mathrm{C}$ lower according to the gradient of carbon isotope fractionation between atmospheric $\mathrm{CO}_{2}$ and DIC of $0.1 \%$ per $1^{\circ} \mathrm{C}$, although this equilibrium is not achieved anywhere, because surface waters are replaced too quickly (Saltzman and Thomas, 2012). A higher atmospheric $\mathrm{pCO}_{2}$ prevailing during the Piedra Alta tsunamite deposition event could have lowered the $\delta^{13} \mathrm{C}$ values of DIC subsequent to equilibration with seawater. Another scenario could involve stronger productivity during the Arucas marine deposit than during the MIS11c interglaciation, when the upwelling may have been diminished, resulting in colder waters that allowed more $\mathrm{CO}_{2}$ to be dissolved.

The two mollusc shells were selected for obtaining isotopic ontogenetic profiles provide complementary information at the seasonal scale between SST and the $\delta^{13} \mathrm{C}$ values of DIC. In the case of the mollusc Cerithium vulgatum (ARU-18-02), the $\delta^{13} \mathrm{C}$ values of the shell and the SST estimates inferred from the $\delta^{18} \mathrm{O}$ values of the shell are linearly correlated, with a slope of -0.31 and an $R^{2}$ of 0.52 . As we already proposed, this correlation may also indicate that there is a temperature-dependent isotopic fractionation between air $\mathrm{CO}_{2}$ and dissolved bicarbonate in the case of the Arucas marine deposit (Bojar et al., 2004). At the seasonal scale, it means that during summer, when SSTs are the highest (Borges et al., 2004), $\delta^{13} \mathrm{C}$ values of DIC are at their lowest. The variation in $\delta^{13} \mathrm{C}$ values of DIC can be assigned, at the seasonal scale, to a change in the activity of the upwelling of the Canary Current, which brings to the surface ancient and ${ }^{13} \mathrm{C}$-depleted waters relative to surface 
waters. Therefore, the Canary Current may have been stronger during the warm season in the Canary Islands during MIS11, which is compatible with the observations made by Mittelstaedt (1991), Navarro-Pérez and Barton (2001), and Pardo et al. (2011) concerning the activity of the Canary Current.

\section{CONCLUSION}

MIS11 is a warm isotope stage considered to be the best reference for understanding the evolution of the MIS1 climate. We have studied two sedimentary marine deposits located in two eastern islands of the Canary archipelago, Lanzarote (Piedra Alta tsunamite) and Gran Canaria (Arucas sedimentary deposit). These marine deposits contain many biogenic skeletal remains of marine origin, which we have studied using Raman spectroscopy to select only the aragonitic skeletal remains for the stable isotope analysis.

Using the bulk oxygen isotope analysis of the aragonitic mollusc shells, SST estimates for MIS11 are $21.2 \pm 1.9^{\circ} \mathrm{C}$ for the Piedra Alta tsunamite (Fig. 3a) and $15.9 \pm 2.2^{\circ} \mathrm{C}$ for the Arucas marine deposit (Fig. 3b) according to available oxygen isotope fractionation equations. The normal distribution of SSTs associated with similar standard deviations for both sites means that coeval populations of molluscs were sampled in each sedimentary marine deposit. These SST estimates, combined with absolute chronological dating and sedimentary and paleontological observations, argue in favor of the deposition of the Arucas marine deposit at the end of Termination $\mathrm{V}$ and the formation of the Piedra Alta tsunamite during MIS11c, which is the warmest period of the interglacial stage MIS11. The SSTs we calculated are consistent with other data suggesting warm temperatures in the central Southern Ocean during MIS11, although these temperatures are not exceptional compared with SSTs recorded for MIS5e.

The carbon isotope measurements for Saccostrea cuccullata and Bolma rugosa, which are present in both marine deposits, show that species from the Arucas deposit are ${ }^{13} \mathrm{C}$-enriched relative to those from Piedra Alta. This isotopic difference may be linked to temperature, atmospheric $\mathrm{pCO}_{2}$, or marine productivity variations that took place between the formation of these two deposits.

The incremental oxygen isotope measurements for Callista chione and Cerithium vulgatum (Fig. 4) revealed sinusoidallike signals that we interpreted as seasonal variations of SST between $3^{\circ} \mathrm{C}$ and $4^{\circ} \mathrm{C}$, an amplitude slightly weaker than the present-day SST documented in the Canary Islands. The carbon isotope measurements performed on Cerithium vulgatum (ARU-18-02) are linearly and negatively correlated to the SST variations, which highlights a stronger activity of the Canary upwelling current during the warm season.

The paleoclimatological data characterizing the early and mid-Pleistocene isotope stages are commonly derived from ice cores and marine and lacustrine sediments, with high latitudes sampled in most cases. However, this study shows that, during MIS11c, the global warming also significantly impacted low-latitude marine regions.

\section{SUPPLEMENTARY MATERIAL}

The supplementary material for this article can be found at https:// doi.org/10.1017/qua.2019.65.

\section{ACKNOWLEDGMENTS}

This study was funded by the Centre National de la Recherche Scientifique and the Institut Universitaire de France (CL). AL and J-FB were supported by PAMEV project (Paleontología de la Macaronesia, Espacio Virtual) ULPGC PEJ-2014-A-83608.

\section{REFERENCES}

[AEMET] Agency of Spain and the Institute of Meteorology, 2012. Climate Atlas of the Archipelagos of the Canary Islands, Madeira and the Azores. AEMET, Portugal.

Augustin, L., Barbante, C., Barnes, P.R., Barnola, J.M., Bigler, M., Castellano, E., Cattani, O., Chappellaz, J., Dahl-Jensen, D., Delmonte, B., 2004. Eight glacial cycles from an Antarctic ice core. Nature 429, 623-628.

Benítez, A., 1912. Historia de las Islas Canarias. Benítez editor, Santa Cruz de Tenerife.

Berger, A., Loutre, M.-F., 2002. An exceptionally long interglacial ahead? Science 297, 1287-1288.

Bintanja, R., Van de Wal, R.S.W., 2008. North American ice-sheet dynamics and the onset of 100,000-year glacial cycles. Nature 454,869

Bojar, A.-V., Hiden, H., Fenninger, A., Neubauer, F., 2004. Middle Miocene seasonal temperature changes in the Styrian basin, Austria, as recorded by the isotopic composition of pectinid and brachiopod shells. Palaeogeography, Palaeoclimatology, Palaeoecology 203, 95-105.

Borges, R., Hernández-Guerra, A., Nykjaer, L., 2004. Analysis of sea surface temperature time series of the south-eastern North Atlantic. International Journal of Remote Sensing 25, 869-891.

Bowen, D.Q., 2003. Uncertainty in Oxygen Isotope Stage 11 sea-level: an Estimate of $13 \pm 2 \mathrm{~m}$ from Great Britain. American Geophysical Union, Washington, DC 137, 131-144.

Candy, I., Schreve, D.C., Sherriff, J., Tye, G.J., 2014. Marine Isotope Stage 11: palaeoclimates, palaeoenvironments and its role as an analogue for the current interglacial. Earth-Science Reviews $128,18-51$

Carracedo, J.C., Day, S., Guillou, H., Badiola, E.R., Canas, J.A., Torrado, F.P., 1998. Hotspot volcanism close to a passive continental margin: the Canary Islands. Geological Magazine 135, 591-604.

Charette, M.A., Smith, W.H., 2010. The volume of Earth's ocean. Oceanography 23, 112-114.

Chase, MW., 1998. NIST-JANAF Thermochemical Tables 4th ed. Journal of Physical and Chemical Reference Data, 1529-1564.

Cloern, J.E., Nichols, F.H., 1978. A von Bertalanffy growth model with a seasonally varying coefficient. Journal of the Fisheries Board of Canada 35, 1479-1482.

Coplen, T.B., Brand, W.A., Gehre, M., Gröning, M., Meijer, H.A., Toman, B., Verkouteren, R.M., 2006. New guidelines for $\delta$ 13C measurements. Analytical Chemistry 78, 2439-2441.

Cornu, S., Pätzold, J., Bard, E., Meco, J., Cuerda-Barcelo, J., 1993. Paleotemperature of the last interglacial period based on $\delta 180$ of Strombus bubonius from the western Mediterranean Sea. Palaeogeography, Palaeoclimatology, Palaeoecology 103, 1-20. 
DeCastro, M., Gómez-Gesteira, M., Costoya, X., Santos, F., 2014. Upwelling influence on the number of extreme hot SST days along the Canary upwelling ecosystem. Journal of Geophysical Research: Oceans 119, 3029-3040.

de Vernal, A., Hillaire-Marcel, C., 2008. Natural variability of Greenland climate, vegetation, and ice volume during the past million years. Science 320, 1622-1625.

Driscoll, E.M., Tinkler, K.J., Hendry, G.L., 1965. The geology and geomorphology of Los Ajaches, Lanzarote. Geological Journal 4, 321-334.

Droxler, A.W., Alley, R.B., Howard, W.R., Poore, R.Z., Burckle, L.H., 2003. Unique and exceptionally long interglacial Marine Isotope Stage 11: window into Earth warm future climate. Earth's Climate and Orbital Eccentricity: The Marine Isotope Stage 11 Question, American Geophysical Union, Washington, DC 137, 1-14.

Elderfield, H., Ferretti, P., Greaves, M., Crowhurst, S., McCave, I.N., Hodell, D.A., Piotrowski, A.M., 2012. Evolution of ocean temperature and ice volume through the mid-Pleistocene climate transition. Science 337, 704-709.

Epstein, S., Mayeda, T., 1953. Variation of O18 content of waters from natural sources. Geochimica et cosmochimica acta 4, 213-224.

Filliben, J.J., 1975. The probability plot correlation coefficient test for normality. Technometrics 17, 111-117.

Flato, G., Marotzke, J., Abiodun, B., Braconnot, P., Chou, S.C., Collins, W., Cox, P., Driouech, F., Emori, S., Eyring, V., 2013. Evaluation of Climate Models. Cambridge University Press, United Kingdom.

Fourel, F., Martineau, F., Tóth, E.E., Görög, A., Escarguel, G., Lécuyer, C., 2016. Carbon and oxygen isotope variability among foraminifera and ostracod carbonated shells. Annales Universitatis Mariae Curie-Sklodowska, sectio AAA-Physica 70, 133.

Friedman, I., O’Neil, J., Cebula, G., 1982. Two new carbonate stable-isotope standards. Geostandards Newsletter 6, 11-12.

Gillet, P., Biellmann, C., Reynard, B., McMillan, P., 1993. Raman spectroscopic studies of carbonates Part I: High-pressure and high-temperature behaviour of calcite, magnesite, dolomite and aragonite. Physics and Chemistry of Minerals 20, 1-18.

Gómez-Letona, M., Ramos, A.G., Coca, J., Arístegui, J., 2017. Trends in primary production in the Canary current upwelling system-a regional perspective comparing remote sensing models. Frontiers in Marine Science 4, 370.

Grossman, E.L., Ku, T.-L., 1986. Oxygen and carbon isotope fractionation in biogenic aragonite: temperature effects. Chemical Geology: Isotope Geoscience Section 59, 59-74.

Hearty, P.J., Kindler, P., Cheng, H., Edwards, R.L., 1999. A + 20 m middle Pleistocene sea-level highstand (Bermuda and the Bahamas) due to partial collapse of Antarctic ice. Geology 27, 375-378.

Helmke, J.P., Bauch, H.A., Röhl, U., Kandiano, E.S., 2008. Uniform climate development between the subtropical and subpolar northeast Atlantic across marine isotope stage 11. Climate of the Past Discussions 4, 433-457.

Ho, S.L., Mollenhauer, G., Lamy, F., Martínez-Garcia, A., Mohtadi, M., Gersonde, R., Hebbeln, D., Nunez-Ricardo, S., Rosell-Melé, A., Tiedemann, R., 2012. Sea surface temperature variability in the Pacific sector of the Southern Ocean over the past 700 kyr. Paleoceanography 27. https://doi.org/10.1029/2012PA002317.

Horita, J., Ueda, A., Mizukami, K., Takatori, I., 1989. Automatic $\delta \mathrm{D}$ and $\delta^{18} \mathrm{O}$ analyses of multi-water samples using $\mathrm{H} 2$-and $\mathrm{CO}_{2}$ -water equilibration methods with a common equilibration set-up. International Journal of Radiation Applications and Instrumentation. Part A. Applied Radiation and Isotopes 40, 801-805.
Howard, W.R., 1997. Palaeoclimatology: a warm future in the past. Nature 388, 418.

Hut, G., 1987. Consultants' group meeting on stable isotope reference samples for geochemical and hydrological investigations, Report to the Director General of the International Atomic Energy Agency.

[IPCC] Intergovernmental Panel on Climate Change, 2014, Climate Change 2014: Synthesis Report. Contribution of Working Groups I, II and III to the Fifth Assessment Report of the Intergovernmental Panel on Climate Change. Geneva, Switzerland.

Jouzel, J., Masson-Delmotte, V., Cattani, O., Dreyfus, G., Falourd, S., Hoffmann, G., Minster, B., Nouet, J., Barnola, J.-M., Chappellaz, J., 2007. Orbital and millennial Antarctic climate variability over the past 800,000 years. Science 317, 793-796.

Kandiano, E.S., Bauch, H.A., Fahl, K., Helmke, J.P., Röhl, U., Pérez-Folgado, M., Cacho, I., 2012. The meridional temperature gradient in the eastern North Atlantic during MIS 11 and its link to the ocean-atmosphere system. Palaeogeography, Palaeoclimatology, Palaeoecology 333-334, 24-39.

Kim, S.-T., Mucci, A., Taylor, B.E., 2007a. Phosphoric acid fractionation factors for calcite and aragonite between 25 and $75 \mathrm{C}$ : revisited. Chemical Geology 246, 135-146.

Kim, S.-T., O’Neil, J.R., Hillaire-Marcel, C., Mucci, A., 2007b. Oxygen isotope fractionation between synthetic aragonite and water: influence of temperature and $\mathrm{Mg}^{2+}$ concentration. Geochimica et Cosmochimica Acta 71, 4704-4715.

Land, L.S., 1967. Diagenesis of skeletal carbonates. Journal of Sedimentary Research 37, 914-930.

Land, L.S., Lang, J.C., Smith, B.N., 1975. Preliminary observations on the carbon isotopic composition of some reef coral tissues and symbiotic zooxanthellae. Limnology and Oceanography 20, 283-287.

Lawrence, K.T., Herbert, T.D., Brown, C.M., Raymo, M.E., Haywood, A.M., 2009. High-amplitude variations in North Atlantic sea surface temperature during the early Pliocene warm period. Paleoceanography 24.

Lécuyer, C., Atrops, F., Amiot, R., Angst, D., Daux, V., Flandrois, J.-P., Fourel, F., Rey, K., Royer, A., Seris, M., 2018. Tsunami sedimentary deposits of Crete records climate during the "Minoan Warming Period" $\approx 3350 \mathrm{yr} \mathrm{BP})$. The Holocene 28, 914-929.

Lécuyer, C., Hutzler, A., Amiot, R., Daux, V., Grosheny, D., Otero, O., Martineau, F., Fourel, F., Balter, V., Reynard, B., 2012. Carbon and oxygen isotope fractionations between aragonite and calcite of shells from modern molluscs. Chemical Geology 332, 92-101.

Lécuyer, C., Reynard, B., Martineau, F., 2004. Stable isotope fractionation between mollusc shells and marine waters from Martinique Island. Chemical Geology 213, 293-305.

Leveque, C., 1971. Équation de von Bertalanffy et croissance des mollusques benthiques du Lac Tchad. Cahiers ORSTOM, series Hydrobiologie 5, 263-283.

Lisiecki, L.E., Raymo, M.E., 2005. A Pliocene-Pleistocene stack of 57 globally distributed benthic $\delta^{18} \mathrm{O}$ records. Paleoceanography 20. https://doi.org/10.1029/2004PA001071.

Loutre, M.-F., Berger, A., 2003. Marine Isotope Stage 11 as an analogue for the present interglacial. Global and Planetary Change 36, 209-217.

Maslin, M.A., Swann, G.E., 2006. Isotopes in marine sediments. In: Isotopes in Palaeoenvironmental Research, Springer, Dordrecht, Netherlands, 227-290.

McCarthy, K.T., Pichler, T., Price, R.E., 2005. Geochemistry of Champagne Hot Springs shallow hydrothermal vent field and 
associated sediments, Dominica, Lesser Antilles. Chemical Geology 224, 55-68.

McConnaughey, T., 1989. ${ }^{13} \mathrm{C}$ and ${ }^{18} \mathrm{O}$ isotopic disequilibrium in biological carbonates: I. Patterns. Geochimica et Cosmochimica Acta 53, 151-162.

McConnaughey, T.A., 2003. Sub-equilibrium oxygen-18 and carbon-13 levels in biological carbonates: carbonate and kinetic models. Coral Reefs 22, 316-327.

McCrea, J.M., 1950. On the isotopic chemistry of carbonates and a paleotemperature scale. Journal of Chemical Physics 18, 849-857.

McManus, J., Oppo, D., Cullen, J., Healey, S., 2003. Marine isotope stage 11 (MIS 11): analog for Holocene and future Climate? Earth's Climate and Orbital Eccentricity: The Marine Isotope Stage 11 Question, American Geophysical Union, Washington, DC 137, 69-85.

Meco, J., 2008. Historia Geológica del Clima en Canarias. Libro electrónico ISBN 84-691-5551-6, 296 pp.

Meco, J., Guillou, H., Carracedo, J.-C., Lomoschitz, A., Ramos, A.-J.G., Rodríguez-Yánez, J.-J., 2002. The maximum warmings of the Pleistocene world climate recorded in the Canary Islands. Palaeogeography, Palaeoclimatology, Palaeoecology 185, 197-210.

Meco, J., Lomoschitz, A., Rodríguez, Á., Ramos, A.J., Betancort, J.F., Coca, J., 2018. Mid and Late Holocene sea level variations in the Canary Islands. Palaeogeography, Palaeoclimatology, Palaeoecology 507, 214-225.

Meco, J., Muhs, D.R., Fontugne, M., Ramos, A.J., Lomoschitz, A., Patterson, D., 2011. Late Pliocene and Quaternary Eurasian locust infestations in the Canary archipelago. Lethaia 44, 440-454.

Meco, J., Stearns, C.E., 1981. Emergent littoral deposits in the eastern Canary Islands. Quaternary Research 15, 199-208.

Medina-Elizalde, M., Lea, D.W., 2005. The mid-Pleistocene transition in the tropical Pacific. Science 310, 1009-1012.

Melles, M., Brigham-Grette, J., Minyuk, P.S., Nowaczyk, N.R., Wennrich, V., DeConto, R.M., Anderson, P.M., Andreev, A.A., Coletti, A., Cook, T.L., 2012. 2.8 million years of Arctic climate change from Lake El'gygytgyn, NE Russia. Science 337, 315-320.

Menéndez, I., Silva, P.G., Martín-Betancor, M., Pérez-Torrado, F.J., Guillou, H., Scaillet, S., 2008. Fluvial dissection, isostatic uplift, and geomorphological evolution of volcanic islands (Gran Canaria, Canary Islands, Spain). Geomorphology 102, 189-203.

Miller, K.G., Kominz, M.A., Browning, J.V., Wright, J.D., Mountain, G.S., Katz, M.E., Sugarman, P.J., Cramer, B.S., Christie-Blick, N., Pekar, S.F., 2005. The Phanerozoic record of global sea-level change. Science 310, 1293-1298.

Miller, K.G., Mountain, G.S., Wright, J.D., Browning, J.V., 2011. A 180-million-year record of sea level and ice volume variations from continental margin and deep-sea isotopic records. Oceanography $24,40-53$.

Mittelstaedt, E., 1991. The ocean boundary along the northwest African coast: circulation and oceanographic properties at the sea surface. Progress in Oceanography 26, 307-355.

Montesinos, M., Ramos, A.J., Lomoschitz, A., Coca, J., Redondo, A., Betancort, J.F., Meco, J., 2014. Extralimital Senegalese species during Marine Isotope Stages 5.5 and 11 in the Canary Islands $(29 \mathrm{~N})$ : sea surface temperature estimates. Palaeogeography, Palaeoclimatology, Palaeoecology 410, 153-163.

Muhs, D.R., Meco, J., Simmons, K.R., 2014. Uranium-series ages of corals, sea level history, and palaeozoogeography, Canary Islands, Spain: an exploratory study for two Quaternary interglacial periods. Palaeogeography, Palaeoclimatology, Palaeoecology 394, 99-118.
Muhs, D.R., Pandolfi, J.M., Simmons, K.R., Schumann, R.R. 2012. Sea-level history of past interglacial periods from uranium-series dating of corals, Curaçao, Leeward Antilles islands. Quaternary Research 78, 157-169. https://doi.org/10. 1016/j.yqres.2012.05.008

Navarro-Pérez, E., Barton, E.D., 2001. Seasonal and interannual variability of the Canary Current. Scientia Marina 65, 205-213.

Olson, S.L., Hearty, P.J., 2009. A sustained $+21 \mathrm{~m}$ sea-level highstand during MIS 11 (400ka): direct fossil and sedimentary evidence from Bermuda. Quaternary Science Reviews 28, 271-285.

Oppo, D.W., McManus, J.F., Cullen, J.L., 2006. Evolution and demise of the Last Interglacial warmth in the subpolar North Atlantic. Quaternary Science Reviews, Critical Quaternary Stratigraphy 25, 3268-3277.

Pardo, P.C., Padín, X.A., Gilcoto, M., Farina-Busto, L., Pérez, F.F., 2011. Evolution of upwelling systems coupled to the long-term variability in sea surface temperature and Ekman transport. Climate Research 48, 231-246.

Paris, R., Bravo, J.J.C., González, M.E.M., Kelfoun, K., Nauret, F., 2017. Explosive eruption, flank collapse and megatsunami at Tenerife ca. 170 ka. Nature Communications 8, 15246.

Paris, R., Ramalho, R.S., Madeira, J., Ávila, S., May, S.M., Rixhon, G., Engel, M., Brückner, H., Herzog, M., Schukraft, G., 2018. Mega-tsunami conglomerates and flank collapses of ocean island volcanoes. Marine Geology 395, 168-187.

Parker, W.G., Yanes, Y., Surge, D., Mesa-Hernández, E., 2017. Calibration of the oxygen isotope ratios of the gastropods Patella candei crenata and Phorcus atratus as high-resolution paleothermometers from the subtropical eastern Atlantic Ocean. Palaeogeography, Palaeoclimatology, Palaeoecology 487, 251-259.

Past Interglacials Working Group of PAGES, 2016. Interglacials of the last 800,000 years. Reviews of Geophysics 54, 162-219.

Perez-Torrado, F.-J., Cabrera, M.C., Carracedo, J.C., Gimeno Torrente, D., Schneider, J.-L., Paris, R., Wassmer, P., Guillou, H., 2002. Depósitos de tsunami en el valle de Agaete, Gran Canaria (Islas Canarias). Geogaceta 32, 75-78.

Prokopenko, A.A., Bezrukova, E.V., Khursevich, G.K., Solotchina, E.P., Kuzmin, M.I., Tarasov, P.E., 2010. Climate in continental interior Asia during the longest interglacial of the past 500000 years: the new MIS 11 records from Lake Baikal, SE Siberia. Climate of the Past 6, 31-48.

Roberts, D.L., Karkanas, P., Jacobs, Z., Marean, C.W., Roberts, R.G., 2012. Melting ice sheets 400,000 yr ago raised sea level by 13m: Past analogue for future trends. Earth and Planetary Science Letters 357-358, 226-237.

Robinson, A., Alvarez-Solas, J., Calov, R., Ganopolski, A., Montoya, M., 2017. MIS-11 duration key to disappearance of the Greenland ice sheet. Nature Communications 8, 16008.

Rohling, E.J., Braun, K., Grant, K., Kucera, M., Roberts, A.P., Siddall, M., Trommer, G., 2010. Comparison between Holocene and Marine Isotope Stage-11 sea-level histories. Earth and Planetary Science Letters 291, 97-105.

Rousseau, D.-D., 2003. The continental record of stage 11: a review. Earth's Climate and Orbital Eccentricity: The Marine Isotope Stage 11 Question, American Geophysical Union, Washington, DC 137, 213-222.

Saltzman, M.R., Thomas, E., 2012. Carbon isotope stratigraphy. In: The Geologic Time Scale, 1, 207-232.

Shackleton, N., 1967. Oxygen isotope analyses and Pleistocene temperatures re-assessed. Nature 215, 15.

Stichler, W., 1995. Interlaboratory comparison of new materials for carbon and oxygen isotope ratio measurements. Reference and 


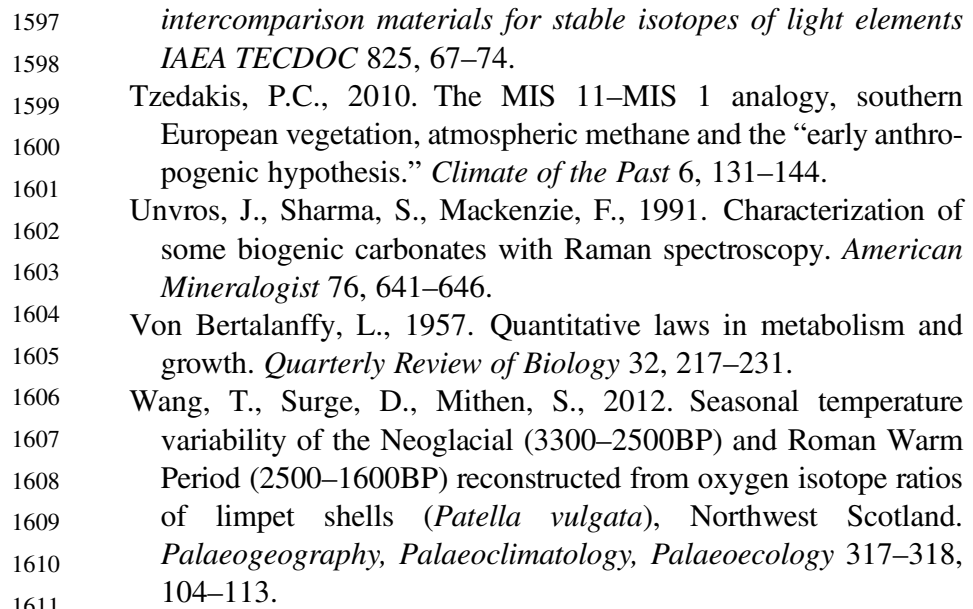

intercomparison materials for stable isotopes of light elements IAEA TECDOC 825, 67-74.

Tzedakis, P.C., 2010. The MIS 11-MIS 1 analogy, southern European vegetation, atmospheric methane and the "early anthropogenic hypothesis." Climate of the Past 6, 131-144.

Unvros, J., Sharma, S., Mackenzie, F., 1991. Characterization of some biogenic carbonates with Raman spectroscopy. American Mineralogist 76, 641-646.

Von Bertalanffy, L., 1957. Quantitative laws in metabolism and growth. Quarterly Review of Biology 32, 217-231.

Wang, T., Surge, D., Mithen, S., 2012. Seasonal temperature variability of the Neoglacial (3300-2500BP) and Roman Warm Period (2500-1600BP) reconstructed from oxygen isotope ratios of limpet shells (Patella vulgata), Northwest Scotland. Palaeogeography, Palaeoclimatology, Palaeoecology 317-318, 104-113.

Wassenaar, L.I., Terzer-Wassmuth, S., Douence, C., Araguas-Araguas, L., Aggarwal, P.K., Coplen, T.B., 2018.
Seeking excellence: an evaluation of 235 international laboratories conducting water isotope analyses by isotope-ratio and laserabsorption spectrometry. Rapid Communications in Mass Spectrometry 32, 393-406.

Watkins, J.M., Hunt, J.D., Ryerson, F.J., DePaolo, D.J., 2014. The influence of temperature, $\mathrm{pH}$, and growth rate on the $\delta^{18} \mathrm{O}$ composition of inorganically precipitated calcite. Earth and Planetary Science Letters 404, 332-343.

Winter, A., Appeldoorn, R.S., Bruckner, A., Williams, E.H., Jr, Goenaga, C., 1998. Sea surface temperatures and coral reef bleaching off La Parguera, Puerto Rico (northeastern Caribbean Sea). Coral Reefs 17, 377-382.

Zazo, C., Goy, J.L., Hillaire-Marcel, C., Gillot, P.-Y., Soler, V., González, J.Á., Dabrio, C.J., Ghaleb, B., 2002. Raised marine sequences of Lanzarote and Fuerteventura revisited-a reappraisal of relative sea-level changes and vertical movements in the eastern Canary Islands during the Quaternary. Quaternary Science Reviews 21, 2019-2046. 